\title{
Social media fatigue pada mahasiswa di masa pandemi COVID-19: Peran neurotisisme, kelebihan informasi, invasion of life, kecemasan, dan jenis kelamin
}

\author{
Wahyu Rahardjo*, Nurul Qomariyah, Indah Mulyani \& Inge Andriani \\ Fakultas Psikologi, Universitas Gunadarma, Depok
}

\begin{abstract}
Abstrak
Tujuan dari penelitian ini adalah untuk menguji secara empiris apakah neurotisisme, kelebihan informasi, invasion of life, dan kecemasan memengaruhi social media fatigue pada mahasiswa yang belajar di rumah karena pandemi COVID-19. Partisipan penelitian ini berjumlah 639 mahasiswa pria dan wanita dari kawasan Jabodetabek dan beberapa kota lain yang aktif menggunakan media sosial sebagai sarana belajar di rumah dan juga mencari dan menerima berbagai informasi. Desain penelitian ini adalah cross-sectional dan non-eksperimental. Hasil penelitian memperlihatkan bahwa secara bertahap masingmasing variabel seperti neurotisisme, kelebihan informasi, invasion of life, dan kecemasan memiliki sumbangan terhadap social media fatigue pada mahasiswa. Namun demikian, pada tahap terakhir ketika kecemasan dipertimbangkan dalam perhitungan, neurotisisme menjadi tidak memiliki sumbangan terhadap social media fatigue. Hasil penelitian ini juga menunjukkan besarnya sumbangan kelebihan informasi terhadap social media fatigue dan lebih rentannya kelompok mahasiswa pria untuk mengalami social media fatigue saat belajar di rumah selama pandemi COVID-19. Besarnya beban kognitif dan kurangnya kemampuan memproses informasi yang ditengarai menjadi penyebab terjadinya social media fatigue. Pihak-pihak terkait seperti perguruan tinggi diharapkan dapat memperhatikan efek belajar di rumah bagi mahasiswa selama pandemi COVID-19.
\end{abstract}

Kata kunci: social media fatigue, mahasiswa, belajar di rumah, COVID-19

\begin{abstract}
The purpose of this study is to examine whether neuroticism, information overload, invasion of life, and anxiety influence social media fatigue in college students studying at home due to the COVID-19 pandemic. Participants in this study is 639 male and female college students from the Greater Jakarta Area and several other cities that actively used social media for studying at home as well for seeking and receiving various information. Research design for this study is non-experimental and cross-sectional. Neuroticism, information overload, invasion of life, and anxiety affecting social media fatigue in college students. However, at the final step in which anxiety was involved in the formula, neuroticism has no effect on social media fatigue. The results of this study also indicate the magnitude of the influence of information overload on social media fatigue and the more vulnerable groups of male students to experience social media fatigue when studying at home during COVID-19 pandemic. The amount of cognitive load and the inability to process information are suspected to be the causes of social media fatigue. Related parties such as universities are expected to pay more attention to the effects of learning at home for students during the COVID-19 pandemic.
\end{abstract}

Keywords: social media fatigue, college students, studying at home, COVID-19

\section{Pendahuluan}

Pada bulan Desember 2019, kasus virus corona baru (2019-nCoV) muncul pertama kali di Wuhan, Cina, dan kemudian WHO menamakan penyakit yang disebabkan virus ini sebagai COVID-19 (WHO, 2020). COVID-19 kemudian berkembang dari epidemi menjadi pandemi, serta menjangkiti penduduk di banyak negara di dunia. Angka kematian akibat COVID-19 meningkat seiring dengan berjalannya waktu. Berdasarkan data hingga akhir bulan Maret 2020, lebih dari 27 negara di dunia sudah menerapkan lockdown atau penutupan wilayah, baik yang 
sifatnya menyuluruh atau sebagian (Secon, Frias, \& McFall-Johnsen, 2020).

Indonesia sendiri belum melakukan lockdown dengan berbagai pertimbangan ekonomi dan kultural (Intan, 2020). Namun demikian, konsep physical distancing diterapkan kepada warga negara untuk meminimalisir penyebaran COVID-19. Physical distancing disebut WHO sebagai pengaturan jarak fisik untuk menghindari penyebaran virus corona secara lebih luas (Mukaromah, 2020). Physical distancing sendiri merupakan kebijakan lanjutan dari social distancing. Social distancing berdampak pada adanya keputusan mengenai perkuliahan jarak jauh daring dalam dunia pendidikan. Hal ini sesuai dengan Surat Edaran Menteri Pendidikan dan Kebudayaan Republik Indonesia Nomor 4 Tahun 2020 tentang pelaksanaan kebijakan pendidikan dalam masa darurat penyebaran COVID-19. Bagi para pekerja, istilah yang populer adalah work from home atau bekerja di rumah, sedangkan bagi para siswa dan mahasiswa, istilah ini menjadi belajar di rumah. Lebih tepatnya "terpaksa" belajar di rumah karena institusi pendidikan "dipaksa" melakukan hal ini karena pandemi COVID-19.

Belajar secara daring tentu bukan hal yang mudah bagi siswa (Gillett-Swan, 2017). Kesulitan muncul bukan hanya perkara keterampilan penggunaan teknologi, tetapi juga terkait dengan beban kerja yang besar mengingat ada banyak mata kuliah yang harus dihadapi dalam masa pandemi COVID-19 ini. Hal ini terjadi karena mahasiswa terbiasa dengan pembelajaran tatap muka secara reguler, sedangkan pembelajaran jarak jauh sebelumnya hanya dilakukan secara insidental. Sehingga perubahan pola pembelajaran ini memberikan permasalahan tersendiri bagi mahasiswa. Studi du Plessis (2019) telah menegaskan munculnya tekanan dan stres pada mahasiswa yang melakukan pembelajaran jarak jauh. Pada titik ini, tekanan tentu menjadi terasa lebih berat, sehingga mahasiswa melakukan banyak coping stress, di mana salah satunya adalah terlibat dengan penggunaan media sosial.

Media sosial sendiri digunakan untuk banyak hal, misalnya coping stress melalui dukungan sosial secara daring dari teman sebaya atau untuk mendapatkan kebahagiaan dan kesejahteraan psikologis karena bersifat menyenangkan, menghibur, dan mengakomodasi pencarian informasi (Fang, Chao, \& Ha, 2017; Munzel, Galan, \& Meyer-Waarden, 2018). Jadi pada titik ini, seharusnya media sosial menjadi salah satu jalan keluar meretas rasa bosan ataupun stres karena belajar di rumah. Hanya saja, keadaan menjadi berbeda selama pandemi COVID-19. Kelebihan informasi telah terbukti menyebabkan social media fatigue karena membebani kognisi indi- vidu (Zhang, Zhao, Lu, \& Yang, 2016). Bersama informasi akademis yang kerap dibagikan lewat media sosial maka berita mengenai COVID-19 ikut lalu lalang secara masif dan tidak terkendali di berbagai media sosial dan berpotensi menimbulkan social media fatigue pada mahasiswa.

Social media fatigue adalah perasaan subjektif pengguna media sosial yang merasa lelah, jengkel, marah, kecewa, kehilangan minat, atau berkurangnya motivasi berkaitan dengan interaksi di berbagai aspek penggunaan media sosial karena banyaknya konten yang ditemui dalam media sosial (Bright, Kleiser, \& Grau, 2015; Ravindran, Kuan, \& Lian, 2014). Social media fatigue merupakan suatu fenomena yang terjadi karena interaksi faktor sosial dan teknologi (Xiao, Mou, \& Huang, 2019). Bagi mahasiswa yang relatif akrab dengan penggunaan teknologi, maka social media fatigue bisa terjadi ketika faktor sosial lebih mendominasi dibandingkan faktor teknologi.

Social media fatigue menyebabkan individu kehilangan konsentrasi dan fokus terhadap apa yang harus dikerjakan (Zhang dkk., 2016). Hal ini memicu konsekuensi negatif lainnya yaitu penurunan performa belajar (Yu, Cao, Liu, \& Wang, 2018). Artinya, mahasiswa yang belajar di rumah selama wabah COVID-19 diduga tidak mampu menampilkan kinerja yang maksimal dan mengalami penurunan prestasi. Temuan sebelumnya telah menegaskan sumbangan social media fatigue terhadap penurunan prestasi akademik pada mahasiswa (Dhir, Kaur, Chen, \& Pallesen, 2019; Malik, Dhir, Kaur, \& Johri, 2020). Beberapa hal lain yang menjadi konsekuensi social media fatigue adalah kondisi emosi yang fluktuatif dan tidak stabil, kegagalan pencapaian well-being, termasuk menghentikan kegiatan yang menggunakan internet (Dhir, Yossatorn, Kaur, \& Chen, 2019; Ravindran, Kuan, \& Lian, 2014).

Ada beberapa hal yang ditengarai memengaruhi social media fatigue. Pertama adalah neurotisisme, yakni merupakan trait kepribadian yang mencerminkan kecenderungan individu untuk mengalami keterpurukan emosi, ketegangan saraf, dan stres (Roos \& Kazemi, 2018). Neurotisisme menurunkan kestabilan emosi (Sonoswka, de Fruyt, \& Hofmans, 2019; Widiger \& Oltmanns, 2017), padahal kestabilan emosi penting dalam membantu individu menghadapi tekanan. Neurotisisme dapat meningkatkan persepsi technostressor pada individu bahwa penggunaan teknologi pada suatu titik dapat dipersepsikan sebagai ancaman (Tarafdar, Cooper, \& Stich, 2019). Orang neurotik cenderung merasa tidak aman, dan ketika keterlibatannya dalam media sosial terlalu tinggi dirinya merasa kehilangan anonimitas dan mengganggu privasi daringnya (Srivastava, Chandra, \& Shirish, 2015). Ketika keadaan 
menyebabkan dirinya tidak mampu mengendalikan media sosial karena berbagai persoalan kontekstual yang sedang terjadi maka kecemasan akan meningkat tajam (Xiao \& Mou, 2019).

Variabel lain yang diduga memengaruhi social media fatigue adalah kelebihan informasi. Kelebihan informasi adalah situasi ketika individu disajikan sejumlah besar informasi di media sosial yang melebihi kapasitas yang dapat mereka proses (Eppler \& Mengis, 2004). Kelebihan informasi yang ditemui di media sosial mempersulit individu memproses informasi sehingga mengakibatkan dirinya mengalami social media fatigue (Bright, Kleiser, \& Grau, 2015; Lee, Son, \& Kim, 2016). Semakin intens informasi yang dipersepsikan menjadi sumber stres maka akan semakin sulit individu mengendalikan beban psikisnya sehingga mengalami social media fatigue.

Hal lain yang juga diduga berkontribusi terhadap social media fatigue adalah invasion of life. Invasion of life adalah persepsi individu bahwa kehidupan pribadinya telah terusik oleh penggunaan media sosial terkait pekerjaan dan tugas (Gaudiso, Turel, \& Galimberti, 2017). Kewajiban seperti pekerjaan yang harus dikerjakan secara daring rentan membuat individu merasa terinvasi kehidupan pribadinya (Yao \& Cao, 2017).

Pada masa pandemi COVID-19, banyak informasi akademik disampaikan dan dibagi melalui media sosial secara terstruktur dan terjadwal. Di saat bersamaan informasi terkait COVID19 yang beraneka ragam dan bersifat negatif membebani pikiran dan psikis mahasiswa. Hal ini membuat individu merasa letih dan tidak nyaman karena merasa ada bagian dari hidupnya yang tidak bisa dilepaskan dari keberadaan media sosial, sehingga mahasiswa harus menghadapi tuntutan akademik dan derasnya informasi negatif tentang COVID-19 melalui dunia maya secara bersamaan. Kaitan invasion of life dan social media fatigue telah terkonfirmasi oleh Xiao dan Mou (2019).

Hal berikutnya yang juga ditengarai memengaruhi social media fatigue adalah kecemasan. Kecemasan adalah suatu pikiran yang meresap secara mendalam sehingga muncul rasa prihatin terhadap situasi atau ancaman yang mungkin dapat terjadi (Stein \& Sareen, 2015). Pada situasi biasa, kecemasan bisa muncul dengan adanya social media fatigue yang terjadi karena penggunaan media sosial yang eksesif (Dhir, Yossatorn, Kaur, \& Chen, 2018; Vannucci, Flannery, \& Ohannessian, 2017). Hanya saja, pandemik COVID19 memberikan keadaan yang berbeda. Fakta informasi terkait peningkatan jumlah orang yang terinfeksi, angka kematian, dan perihal lockdown memungkinkan individu mengalami kecemasan. Temuan Ahorsu, Lin, Imani, Saffari, Griffiths, dan Pakpour (2020) menegaskan bahwa segala hal yang terkait dengan COVID-19 memang membawa beberapa konsekuensi psikologis seperti rasa takut dan khawatir pada banyak orang. Kecemasan karena berbagai berita terkait COVID-19 ini potensial memunculkan social media fatigue.

Zhou dan Zhang (2019) menyebutkan bahwa jenis kelamin bisa jadi memainkan peranan terkait social media fatigue meskipun hal ini juga harus memperhitungkan durasi penggunaan media sosial. Studi Ravindran, Kuan, dan Lian (2014) telah menjelaskan bahwa perbedaan social media fatigue berdasarkan jenis kelamin hanya terlihat sekilas dalam proses wawancara, sedangkan variasi temuannya tidak tampak secara kuantitatif. Hal ini menjelaskan bahwa terdapat kontradiksi hasil penelitian social media fatigue berdasarkan jenis kelamin dan perlu diteliti lebih lanjut, terlebih lagi jika dikaitan dengan konteks seperti pandemi COVID-19.

Riset-riset terkait social media fatigue sebelumnya hanya menyasar persoalan psikologi siber (cyberpsychology) dan psikologi sosial. Di dalam masa pandemi COVID-19 ini, keterlibatan individu dengan media sosial sebagai wadah komunikasi sosial, sekaligus informasi akademis dan penyebaran virus corona menjadi lebih kontekstual karena situasi yang terjadi rentan menyebabkan social media fatigue dengan mempertimbangkan berbagai faktor internal dan eksternal. Berdasarkan alasan dan argumentasi teoretik yang telah dipaparkan sebelumnya maka hipotesis penelitian ini adalah terdapat hubungan neurotisisme, kelebihan informasi, invasion of life, dan kecemasan terhadap social media fatigue pada mahasiswa yang belajar di rumah selama pandemi COVID-19. Pada penelitian ini juga mencoba untuk mengeksplorasi (1) alasan-alasan tentang mengapa informasi yang banyak ditemui di media sosial dirasakan mengganggu, dan (2) perbedaan jenis kelamin dalam melihat variabel-variabel di atas.

\section{Metode Penelitian}

\section{Partisipan}

Partisipan penelitian ini adalah 639 mahasiswa yang dijangkau dengan menggunakan kuesioner daring. Tautan kuesioner daring disebar secara snowball menggunakan relasi hubungan antar peneliti dan dosen untuk dibagikan ke mahasiswa di beberapa universitas dalam waktu satu minggu mulai dari 29 Maret 2020 hingga 4 April 2020.

Kuesioner daring yang disebar berisi informed consent, identitas partisipan, serta sejumlah skala dari setiap variabel. Di bagian pengantar kuesioner daring disebutkan kriteria inklusi partisipan, yaitu (1) mahasiswa aktif pria dan 
wanita yang berusia minimal 18 tahun, dan (2) sedang berada dalam keadaan belajar di rumah selama perkuliahan karena pandemi COVID-19. Terdapat pula pernyataan yang memberikan kebebasan bagi calon partisipan untuk melewatkan tautan yang didapatkan jika memang kurang berkenan. Tidak ada paksaan untuk menyebarkan maupun mengisi kuesioner daring ini.

Rerata usia partisipan adalah 20,51 tahun $(\mathrm{SD}=2.04)$. Mayoritas partisipan adalah mahasiswa perempuan sebanyak 466 orang $(72,92 \%)$, sedangkan sisanya adalah mahasiswa pria sebanyak 173 orang $(27,07 \%)$. Mayoritas partisipan tinggal di Jakarta $(\mathrm{N}=174 ; 23,23 \%)$, diikuti oleh Bekasi $\quad(\mathrm{N}=123 ; 19,24 \%), \quad$ Tangerang $\quad(\mathrm{N}=86$; $13,45 \%)$, Depok $(\mathrm{N}=59 ; 9,23 \%)$, Bogor $(\mathrm{N}=52$; $8,13 \%)$, Surabaya $(\mathrm{N}=40 ; 6,25 \%)$, Yogyakarta $(\mathrm{N}=27 ; 4,22 \%)$, Surakarta $(\mathrm{N}=3,28 \%)$, Bandung $(\mathrm{N}=17 ; 2,66 \%)$. Malang ( $\mathrm{N}=11 ; 1,72 \%)$, Semarang $(\mathrm{N}=5 ; 0,78 \%)$, Sukabumi $(\mathrm{N}=3 ; 0,46 \%)$, dan lainnya $(\mathrm{N}=21 ; 3,28 \%)$.

\section{Desain}

Penelitian ini merupakan penelitian berjenis kuantitatif. Desain penelitian yang digunakan adalah cross-sectional dan non eksperimental.

\section{Alat Ukur}

Social media fatigue. Di dalam penelitian ini social media fatigue diukur dengan menggunakan skala yang ditranslasi dan diadaptasi dari Bright, Kleiser, dan Grau (2015). Skala ini terdiri dari 5 item. Contoh item dari skala ini adalah "Saya merasa menerima terlalu banyak informasi saat sedang mencari sesuatu di media sosial". Skala ini memiliki kategori respons mulai dari Sangat Tidak Sesuai hingga Sangat Sesuai dengan rentang skor 1-5 dengan $\alpha=0,800$.

Neurotisisme. Di dalam penelitian ini neurotisisme diukur dengan menggunakan cukilan skala Big Five versi Indonesia yang diadopsi dari Ramdhani (2012) yang berjumlah 4 item. Diawali dengan kalimat "Saya adalah orang yang.......", contoh dari item ini adalah "Mudah murung". Skala ini memiliki kategori respons mulai dari Sangat Tidak Setuju hingga Sangat Setuju dengan rentang skor 1-7 dengan $\alpha=0,876$.

Kelebihan informasi. Di dalam penelitian ini kelebihan informasi diukur dengan skala yang ditranslasi dan diadaptasi dari Karr-Wisniewksi dan Lu (2010). Skala ini terdiri dari 3 item. Contoh item dari skala ini adalah "Saya merasa kerepotan dalam memproses banyaknya informasi yang saya terima sehari-hari di media sosial". Skala ini memiliki kategori respons mulai dari Sangat Tidak Sesuai hingga Sangat Sesuai dengan rentang skor 1-5 dengan $\alpha=0 ., 865$.

Invasion of life. Di dalam penelitian ini invasion of life diukur dengan skala yang ditranslasi dan diadaptasi dari Xiao dan Mou (2019). Skala ini terdiri dari 4 item. Contoh item dari skala ini adalah "Menggunakan media sosial meleburkan batasan antara pekerjaan atau studi dengan kehidupan pribadi saya". Untuk keperluan penelitian agar sesuai dengan konteks maka kata "WeChat" yang merupakan media sosial khas Cina diganti menjadi "media sosial". Skala ini memiliki kategori respons mulai dari Sangat Tidak Sesuai hingga Sangat Sesuai dengan rentang skor 1-5 dengan $\alpha=0,622$.

Kecemasan. Di dalam penelitian ini kecemasan diukur dengan menggunakan skala Generalized Anxiety Disorder (GAD-7) yang ditranslasi dan diadaptasi dari Spitzer, Kroenke, Williams, dan Löwe (2006). Skala kecemasan ini terdiri dari 7 butir item. Skala ini diawali dengan dengan kalimat penghantar "Dalam 2 minggu belakangan ini, terkait pemberitaan dan ancaman virus Corona (COVID-19) di Indonesia, seberapa sering Anda terganggu dengan beberapa permasalahan berikut ini?". Salah satu contoh itemnya adalah "Merasa takut seolah-olah sesuatu yang buruk akan terjadi". Skala ini memiliki kategori respons mulai dari sama sekali tidak yakin terjadi hingga setiap hari dengan rentang 0-3 dengan $\alpha=0,864$.

Pada penelitian ini juga mencantumkan pertanyaan eksploratif tambahan. Pertanyaan eksploratif ini dimaksudkan untuk mengatahui alasan mengenai informasi di media sosial yang mengganggu yang tidak tergali dalam skala.

\section{Teknik Analisis}

Teknik analisis data utama yang dipergunakan dalam penelitian ini adalah regresi hierarki. Tahapan analisa yang dilakukan dalam riset ini adalah melakukan korelasi antar variabel terlebih dahulu, dan kemudian dilanjutkan dengan regresi hierarki. Setiap langkah dilakukan untuk melihat kekuatan prediksi masing-masing variabel. Dengan kata lain, tidak masalah variabel apa yang muncul pada setiap tahap. 
Tabel 1.

Alasan mengapa informasi dan berita di media sosial sudah dirasa mengganggu partisipan

\begin{tabular}{lc}
\hline \multicolumn{1}{c}{ Alasan } & Disebut sebanyak \\
\hline Merasa stress & $426(36,56 \%)$ \\
Banyak hoaks & $354(30,38 \%)$ \\
Tumpang tindih satu dengan yang lain & $273(23,43 \%)$ \\
Mengganggu aktivitas berselancar di dunia maya & $100(8,58 \%)$ \\
Mengganggu aktivitas di luar rumah & $12(1,03 \%)$ \\
\hline
\end{tabular}

Tabel 2.

Matriks korelasi antar variabel

\begin{tabular}{|c|c|c|c|c|c|c|}
\hline & 1 & 2 & 3 & 4 & 5 & 6 \\
\hline \multicolumn{7}{|l|}{ Durasi dalam satu hari } \\
\hline Social media fatigue & $-0,151^{* *}$ & & & & & \\
\hline Neurotisisme & $0,133^{* *}$ & $0,183^{* *}$ & & & & \\
\hline Kelebihan informasi & $0,167^{* *}$ & $0,828^{* *}$ & $0,163^{* *}$ & & & \\
\hline Invasion of life & $-0,034$ & $0,497^{* *}$ & 0,041 & $0,465^{* *}$ & & \\
\hline Kecemasan & $-0,025$ & $0,549 * *$ & $0,401^{* *}$ & $0,515^{* *}$ & $0,348^{* *}$ & \\
\hline Rerata & 3,27 & 17,77 & 15,07 & 10,66 & 15,35 & 8,68 \\
\hline SD & 1,00 & 3,60 & 5,08 & 2,91 & 2,33 & 4,68 \\
\hline
\end{tabular}

Keterangan: 1 = durasi penggunaan media sosial dalam satu hari, 2 = social media fatigue,

$3=$ neurotisisme, $4=$ kelebihan informasi, $5=$ invasion of life, $6=$ kecemasan, ${ }^{*}=p<.05,{ }^{* *}=p<.01$

\section{Hasil Penelitian}

Pada Tabel 1 diketahui alasan-alasan yang dikemukakan mengapa informasi yang banyak ditemui di media sosial dirasakan mengganggu oleh partisipan. Dua alasan yang paling banyak disebut adalah membuat stres, dan diikuti oleh banyaknya hoaks. Sementara itu, pada Tabel 2 tampak bahwa social media fatigue memiliki korelasi positif yang signifikan dengan neurotisisme, kelebihan informasi, invasion of life, dan kecemasan.

Berdasarkan Tabel 3 diketahui nilai R2 model 4 adalah $0,717(\mathrm{p}<0,01)$. Namun demikian, pada model terakhir terlihat bahwa neurotisisme tidak signifikan sebagai prediktor social media fatigue meskipun sumbangan totalnya sebesar $71,7 \%$.

Tabel 3.

Rangkuman regresi hierarki setiap variabel bebas terhadap social media fatigue

\begin{tabular}{|c|c|c|c|c|c|c|}
\hline Variabel & $\beta$ & $\mathrm{t}$ & $\mathrm{R}$ & $\mathrm{R}^{2}$ & $\Delta \mathrm{R}^{2}$ & $\Delta \mathrm{F}$ \\
\hline Model 1 & & & ,183 & ,033 & ,033 & $21,998 * *$ \\
\hline Neurotisisme & , 183 & $4,690 * *$ & & & & \\
\hline Model 2 & & & ,829 & 688 & 687 & $699,795^{* *}$ \\
\hline Neurotisisme & 049 & $2,174^{*}$ & & & & \\
\hline Kelebihan informasi & ,820 & $36,492 * *$ & & & & \\
\hline Model 3 & & & ,839 & ,704 & ,703 & $503,411^{* *}$ \\
\hline Neurotisisme & ,054 & $2,467^{*}$ & & & & \\
\hline Kelebihan informasi & 751 & $30,395^{* *}$ & & & & \\
\hline Invasion of life & , 145 & $5,938^{* *}$ & & & & \\
\hline Model 4 & & & ,847 & ,717 & ,715 & $402,031^{* *}$ \\
\hline Neurotisisme & 005 & ,229 & & & & \\
\hline Kelebihan informasi & 694 & $26,329 * *$ & & & & \\
\hline Invansion of life & ,122 & $5,053^{* *}$ & & & & \\
\hline Kecemasan & ,147 & $5,448^{* *}$ & & & & \\
\hline
\end{tabular}

Keterangan: ${ }^{* *} p<.01,{ }^{* *} p<.05$

Pada Tabel 4 juga tampak bahwa pada setiap model terjadi peningkatan sumbangan dari masing-masing variabel bebas terhadap social media fatigue. Sumbangan terbesar disumbangkan oleh variabel kelebihan informasi, baik pada model $2(\beta=0,820)$, model $3(\beta=0,751)$, dan model $4(\beta=0,694)$. Temuan lainnya adalah sumbangan neurotisisme menjadi tidak signifikan, dan sumbangan variabel kelebihan informasi dan invasion of life menjadi tereduksi ketika kecemasan dimasukkan ke dalam perhitungan. 
Sebagai analisis tambahan, penelitian ini juga menguji perbedaan lima variabel berdasarkan jenis kelamin. Berdasarkan Tabel 4 diketahui bahwa tidak ada perbedaan kecemasan berdasarkan jenis kelamin, sementara sisanya ada. Mahasiswa pria memiliki skor social media fatigue, kelebihan informasi, dan invasion of life yang lebih tinggi dibandingkan mahasiswa wanita. Sebaliknya, mahasiswa wanita memiliki skor neurotisisme lebih tinggi dibandingkan mahasiswa pria.

Tabel 4.

Perbedaan antar variabel penelitian berdasarkan jenis kelamin partisipan

\begin{tabular}{lccc}
\hline \multicolumn{1}{c}{ Variabel } & Pria & Wanita & $t$ \\
\hline Social media fatigue & $18,58(3,81)$ & $17,46(3,47)$ & $3,532^{* *}$ \\
Neurotisisme & $14,00(4,46)$ & $15,46(5,24)$ & $-3,528^{* *}$ \\
Kelebihan informasi & $11,33(3,11)$ & $10,42(2,79)$ & $3,555^{* *}$ \\
Invansion of life & $15,78(2,33)$ & $15,19(2,32)$ & $2,836^{* *}$ \\
Kecemasan & $8,83(4,54)$ & $8,63(4,73)$ &, 469 \\
\hline
\end{tabular}

Keterangan: ${ }^{* *} p<, 01$

\section{Diskusi}

Merasa stres dan banyaknya hoaks atau berita bohong merupakan dua alasan yang paling banyak disebut oleh partisipan yang merasa terganggu dengan maraknya berbagai berita terkait COVID-19. Studi Garrett, Gonzales-Garzon, Foulkes, Levita, dan Sharot (2018) menjelaskan bahwa pikiran lebih peka terhadap berita buruk, dan pengaruhnya lebih mudah dirasakan oleh mereka yang telah tertekan secara psikologis. Respon 'merasa stres' paling banyak ditemui pada wanita. Hal ini dimungkinkan karena wanita lebih reaktif dan mudah stres saat membaca dan menerima berita buruk dibandingkan pria (Marin, Morin-Major, Schramek, Beaupre, Perna, Juster, \& Lupien, 2012). Di sisi lain, partisipan akan merasa tidak nyaman ketika membaca berita hoaks karena secara alami otak berusaha menolak segala hal yang dirasa tidak akurat hingga menjadi imun dengan informasi-informasi lain yang senada yang mengandung tidak akurat (Rapp \& Salovich, 2018; Roozenbeek \& van der Linden, 2019).

Individu membutuhkan energi ekstra untuk dapat memproses banyaknya informasi yang dilihat di media sosial-proses inilah yang rentan menyebabkan individu untuk mengalami fatigue (Ravindran, Kuan, \& Lian, 2014). Mencerna informasi yang berlebihan tidak mudah untuk dilakukan. Studi Hwang, Hong, Tai, Chen, dan Gouldthorp (2020) menyebutkan bahwa kelebihan informasi akan menyebabkan individu mengalami beban kognitif. Jika beban kognitif berlangsung dalam kurun waktu yang lama, secara biologis dan emosional akan membuat individu merasa fatigue dan terganggu kesehatan mentalnya (Mizuno, dkk., 2011; Pawar, Jacques, Deshpande, Pusapati, \& Meguerdichian, 2018). Hal ini dipertegas dengan temuan Guo, Lu, Kuang, dan Wang (2020) yang menyatakan bahwa durasi individu terpapar informasi yang berlebihan memperparah terjadinya social media fatigue.

Sebagai salah satu aspek sosial, kepedulian yang tinggi terhadap COVID-19 membuat informasi tentang COVID-19 yang diterima individu kian berlebih sehingga dapat menyebabkan fatigue. Kepedulian yang tinggi terhadap sesuatu hal yang mengarahkan pada penerimaan informasi yang berlebih memengaruhi social media fatigue yang dirasakan (Shokouhyar, Siadat, \& Razavi, 2018; Zhou \& Li, 2014). Di dalam situasi pandemi, media sosial tetap harus diperhatikan oleh mahasiswa mengingat banyaknya informasi akademis yang diberikan terkait perkuliahan. Keharusan melihat media sosial mendorong individu mengalami social media fatigue yang lebih berat (Shokouhyar, Siadat, \& Razavi, 2018).

Senada dengan temuan Xiao dan Mou (2019), hasil penelitian ini juga menunjukkan bahwa ketika di media sosial individu merasa tidak nyaman, di mana batas pribadinya dilanggar serta diambil sebagian hidupnya sehingga mereka semakin kuat mengalami social media fatigue. Pada titik ini, mahasiswa merasakan hidupnya terinvasi ketika relasinya dengan media sosial sudah kehilangan unsur hedonistik dan lebih kepada keharusan karena terkait dengan keperluan perkuliahan selama belajar di rumah. Banyaknya informasi COVID-19 yang membombardir kognisinya di berbagai media sosial juga membuat mahasiswa mengalami social media fatigue. Individu tidak memiliki pilihan lain dan menempatkan media sosial sebagai hal krusial saat itu (Maier, Laumer, Weinert, \& Weitzel, 2015). Semakin kabur batasan antara pekerjaan atau hal lain yang harus dikerjakan dengan kehidupan personal di media sosial karena konteks situasi khusus tertentu, maka akan semakin besar invasion of life dirasakan (Tarafdar, Tu, RaguNathan, \& Ragu-Nathan, 2007), dan semakin 
besar pula kemungkinan terjebak dalam social media fatigue (Xiao \& Mou, 2019).

Invasion of life ini menjadi lebih mudah terjadi ketika individu merasa bahwa privasinya telah diterobos dan dirinya tidak memiliki banyak pilihan untuk hal itu. Westin (dalam Margulis, 2011) menyebutkan privasi merupakan cara individu memproteksi dirinya dengan memberikan akses komunikasi yang terbatas kepada orang lain. Privasi adalah proses yang dinamis karena membantu individu beradaptasi dengan kondisi emosional dalam interaksi interpersonal seharihari. Salah satu tujuan privasi adalah emotional release di mana individu bisa bebas dari tekanan hidup, tuntutan sosial, dan beberapa hal lain. Tidak terpenuhinya tujuan privasi ini menunjukkan individu kehilangan kesempatan mendapatkan time out dari tuntutan sosial.

Semakin intens individu terlibat dengan media sosial maka semakin tipis batasan antara hidupnya dan tugas-tugas perkuliahan. Mungkin saja ada waktu di mana individu merasa harus beristirahat, tetapi tetap harus memonitor informasi di media sosial terkait dengan semua mata kuliah serta tugas-tugasnya secara daring selama pandemi COVID-19. Individu semakin merasa tidak memiliki hidupnya karena aktivitas keseharian banyak terbagi terkait tuntutan-tuntutan akademis. Semakin jauh individu merasa kehilangan privasinya maka akan semakin besar social media fatigue yang dirasakan (Dhir, Kaur, Chen, \& Pallesen, 2019; Xiao \& Mou, 2019).

Kecemasan juga memainkan kontribusi penting dalam temuan ini. Kecemasan dan ketakutan muncul setelah individu banyak terpapar informasi-informasi terkait COVID-19 di berbagai media sosial mereka (Ahorsu, dkk., 2020). Hal ini semakin memperburuk tekanan yang telah dirasakan sebelumnya.

Temuan riset ini menunjukan bahwa ketika kecemasan dihadirkan bersama dengan neurotisisme, maka sumbangan kecemasan sebagai prediktor dari social media fatigue menjadi tidak signifikan dibandingkan dengan ketika kecemasan menjadi prediktor tunggal. Hal ini dikarenakan tiga hal. Pertama, sejak tahap regresi dilakukan sumbangan neurotisisme memang ada, tetapi tidak terlalu kuat sehingga masuknya kecemasan membuat besar sumbangannya tertutupi. Kedua, kecemasan bisa jadi berperan sebagai mediator antara neurotisisme dengan social media fatigue. Hal ini umum terjadi pada persamaan regresi hierarki. Ketiga, neurotisisme berkaitan dengan kecemasan. Studi Booth, Murray, Marples dan Batey (2013) menemukan bahwa neurotisisme memicu munculnya kecemasan, terutama pada individu yang memang sudah berada dalam kondisi yang tertekan. Pada akhirnya, kecemasan muncul sebagai manifes dari keberadaan neuro- tisisme. Hal ini dapat terjadi karena pada dasarnya individu merubah ekspresi perilaku yang ditampilkan meskipun sama-sama merepresentasikan tekanan yang dialami, apakah itu kecemasan atau stres (Mohiyeddini, Bauer, \& Semple, 2015).

Temuan lain dari penelitian ini menunjukkan bahwa mahasiswa pria lebih rentan menerima kelebihan informasi di media sosial, merasa terinvasi hidupnya, lebih mudah merasa cemas, dan mengalami social media fatigue. Hal ini menarik untuk dibahas mengingat di riset sebelumnya, pria memiliki kecemasan dan level stres yang lebih rendah dari wanita (Wang, dkk, 2007). Lebih tingginya kecemasan pada pria sebetulnya dapat dijelaskan dari tingginya invasion of life, dan social media fatigue dibandingkan pada partisipan wanita. Beberapa studi menunjukkan bahwa pria cenderung lebih rentan terhadap berlebihnya beban kognitif, sedangkan wanita memiliki toleransi yang lebih besar terhadap beban kognitif (Hwang, Hong, Cheng, Peng, \& Wu, 2013; Strombach, Margittai, Gorczyca, \& Kalenscher, 2016).

Dominasi sumbangan kelebihan informasi terhadap social media fatigue yang dialami oleh mahasiswa yang belajar di rumah dan peran perasaan bahwa aktivitas berinternet telah mengambil banyak aspek dalam kehidupan pribadi individu merupakan hal yang penting untuk dibahas secara utuh, terutama berkaitan dengan tekanan kecemasan terkait COVID-19. Teori person-environmental fit memperlihatkan bahwa fatigue bisa muncul karena tekanan yang berlebihan, baik itu dari sisi kognitif maupun psikologis yang terjadi karena ketidakseimbangan tuntutan lingkungan dan kemampuan individu untuk mengatasi masalah (Cao \& Yu, 2019; Edwards \& Cooper, 1990). Person-environmental fit memberikan pandangan bahwa masalah pada individu terjadi ketika dirinya kehilangan kendali personal terhadap apa yang terjadi pada dirinya, terutama ketika berada dalam kondisi pekerjaan yang berubah karena persoalan kesehatan dan keamanan (Bridger, Brasher, \& Bennett, 2013; Caplan \& Harrison, 1993). Pada titik ini, penggunaan media sosial yang berlebihan menciptakan kondisi yang tidak seimbang antara jumlah informasi yang diserap dengan kemampuan individu dalam memprosesnya (Cao \& Yu, 2019; Hsu \& Lin, 2017; Xiao \& Mou, 2019).

Dalam hal ini, individu menemui kesulitan untuk bisa mengatasi begitu banyaknya informasi dan meninggalkan media sosialnya sebab hal ini terkait dengan kebutuhan akademis untuk belajar di rumah karena pandemi COVID-19. Seiring dengan berjalannya waktu, individu merasa kehidupan pribadinya menjadi terlanggar karena proses belajar ini memakan banyak waktu dan energi. Hal ini diperparah dengan kecemasan 
akan COVID-19 terkait perkembangan fakta di lapangan yang dinamis dan fluktuatif. Pada akhirnya, hal ini memengaruhi relasi individu dengan media sosialnya dan memunculkan social media fatigue.

\section{Kesimpulan}

Ada beberapa hal penting yang ditemukan dalam riset ini. Pertama, keberadaan mahasiswa yang belajar di rumah karena pandemi COVID-19 rentan mengalami social media fatigue karena media sosial yang biasa digunakan sebagai coping stress dalam kasus ini menjadi sumber stres baru. Kedua, neurotisisme, kelebihan informasi, invasion of life, dan kecemasan secara bersama-sama berhubungan dengan social media fatigue pada mahasiswa. Ketiga, kelebihan informasi menjadi anteseden paling dominan dalam memengaruhi terjadinya social media fatigue pada mahasiswa. Keempat, mahasiswa pria adalah kelompok yang lebih rentan mengalami social media fatigue.

Keterbatasan penelitian ini adalah terkait kontrol, apakah betul semua partisipan hanya menggunakan media sosial sebagai medium informasi akademis dan tidak aplikasi lainnya. Hal ini dapat dijadikan pertimbangan bagi riset selanjutnya untuk lebih memperhatikan persoalan media sosial yang digunakan, serta tipe kepribadian lain yang mungkin lebih memiliki sumbangan terhadap social media fatigue pada mahasiswa.

\section{Daftar Pustaka}

Ahorsu, D. K., Lin, C. Y., Imani, V., Saffari, M., Griffiths, M. D., \& Pakpour, A. H. (2020). The Fear of COVID-19 Scale: Development and initial validation. International Journal of Mental Health and Addiction. https://doi.org/10.1007/s11469-02000270-8

Booth, T., Murray, A. L., Marples, K., \& Batey, M. (2013). What role does neuroticism play in the association between negative job characteristics and anxiety and depression? Personality and Individual Differences, 55(4), 422-427. https://doi.org/10.1016/j.paid.2013.04.0 01

Bridger, R. S., Brasher, K., \& Bennett, A. (2013). Sustaining person-environment fit with a changing workforce. Ergonomics, 56(3), 565-577. https://doi.org/10.1080/00140139.2012. 718369

Bright, L. F., Kleiser, S. B., \& Grau, S. L. (2015). Too much Facebook? An exploratory examination of social media fatigue.
Computers in Human Behavior, 44, 148155. https://doi.org/10.1016/j.chb.2014.11.04 8

Caplan, R. D., \& Harrison, R. (1993). PersonEnvironment Fit Theory: Some history, recent developments, and future directions. Journal of Social Issues, 49(4), 253-275. https://doi.org/10.1111/j.15404560.1993.tb01192.x

Cao, X., \& Yu, L. (2019). Exploring the influence of excessive social media use at work: A three-dimensions usage perspective. International Journal of Information Management, 46, 83-92. https://doi.org/10.1016/j.ijinfomgt.2018. 11.019

Dhir, A., Kaur, P., Chen, S., \& Pallesen, S. (2019). Antecedents and consequences of social media fatigue. International Journal of Information Management, 48, 193-202. https://doi.org/10.1016/j.ijinfomgt.2019. 05.021

Dhir, A., Yossatorn, Y., Kaur, P., \& Chen, S. (2018). Online social media fatigue and psychological well-being - A study of compulsive use, fear of missing out, fatigue, anxiety and depression. International Journal of Information Management, $\quad 40, \quad$ 141-152. https://doi.org/10.1016/j.ijinfomgt.2018. 01.012

du Plessis, M. (2019). Coping with occupational stress in an open distance learning university in South Africa. Journal of Psychology in Africa, 29(6), 570-575. https://doi.org/10.1080/ 14330237.2019.1689466

Edwards, J. R., \& Cooper, C. L. (1990). The personenvironment fit approach to stress: Recurring problems and some suggested solutions. Journal of Organizational Behavior, 11(4), 293-307. https://doi.org/10.1002/job.4030110405

Eppler, M. J., \& Mengis, J. (2004). The concept of information overload: A review of literature from organization science, accounting, marketing, MIS, and related disciplines. The Information Society, 20(5), 325-344. https://doi.org/10.1080/ 01972240490507974

Fang, L., Chao, C. C., \& Ha, L. (2017). College students' positive strategic SNS involvement and stress coping in the United States and China. Journal of Intercultural Communication Research, 46(6), 518-536. https://doi.org/10.1080/ 17475759.2017.1383296 
Garrett, N., González-Garzón, A. M., Foulkes, L., Levita, L., \& Sharot, T. (2018). Updating beliefs under perceived threat. The Journal of Neuroscience, 38(36), 7910-7911. https://doi.org/10.1523/jneurosci.071618.2018

Gaudiso, F., Turel, O., \& Galimberti, C. (2017). The mediating role of strain facets and coping strategies in translating techno-stressors into adverse job outcomes. Computers in Human Behavior, 69, 189-196. https://doi.org/10.1016/j.chb.2016. 12.041

Gillett-Swan, J. (2017). The challenges of online learning: Supporting and engaging the isolated learner. Journal of Learning Design, 10(1), 20-30.

Guo, Y., Lu, Z., Kuang, H., \& Wang, C. (2020). Information avoidance behavior on social network sites: Information irrelevance, overload, and the moderating of time pressure. International Journal of Information Management, 52, 102067. https://doi.org/10.1016/ j.ijinfomgt.2020.102067

Hsu, M. H., \& Lin, H. C. (2017). An investigation of the impact of cognitive absorption on continued usage of social media in Taiwan: the perspectives of fit. Behaviour \& Information Technology, 36(8), 768-791. https://doi.org/10.1080/0144929x.2017. 1288267

Hwang, M. Y., Hong, J. C., Tai, K. H., Chen, J. T., \& Gouldthorp, T. (2019). The relationship between the online social anxiety, perceived information overload and fatigue, and job engagement of civil servant LINE users. Government Information Quarterly, 37, 101423. https://doi.org/10.1016/j.giq.2019.10142 3

Hwang, M. Y., Hong, J. C., Cheng, H. Y., Peng, Y. C., $\& \mathrm{Wu}$, N. C. (2013). Gender differences in cognitive load and competition anxiety affect 6th grade students' attitude toward playing and intention to play at a sequential or synchronous game. Computers \& Education, 60(1), 254-263. https://doi.org/10.1016/j.compedu.2012. 06.014

Intan, G. (2020). Kenapa Indonesia tidak 'lockdown'? Ini jawaban Jokowi. Diunggah dari

https://www.voaindonesia.com/a/kenapa -indonesia-tidak-lockdown-ini-jawa banjokowi/5343239.html pada 15 April 2020.

Karr-Wisniewski, P., \& Lu, Y. (2010). When more is too much: Operationalizing technology overload and exploring its impact on knowledge worker productivity. Computers in Human Behavior, 26(5), 1061-1072.

https://doi.org/10.1016/j.chb.2010.03. 008

Kementerian Pendidikan Republik Indonesia. (2020). Surat Edaran No 4 Tahun 2020

Tentang Pelaksanaan Kebijakan Pendidikan dalam Masa Darurat Penyebaran Corona Virus Disease (COVID19). Jakarta: Kementerian Pendidikan Republik Indonesia.

Lee, A. R., Son, S. M., \& Kim, K. K. (2016). Information and communication technology overload and social networking service fatigue: A stress perspective. Computers in Human Behavior, 55, 51-61. https://doi.org/10.1016/j.chb.2015.08.01 1

Maier, C., Laumer, S., Weinert, C., \& Weitzel, T. (2015). The effects of technostress and switching stress on discontinued use of social networking services: A study of Facebook use. Information Systems Journal, 25(3), 275-308. https://doi.org/10.1111/isj.12068

Malik, A., Dhir, A., Kaur, P., \& Johri, A. (2020). Correlates of social media fatigue and academic performance decrement: A large-cross sectional study. Information Technology \& People. https://doi.org/10.1108/ITP-06-2019028

Margulis, S. T. (2011). Three theories of privacy: An overview. Dalam S. Trepte \& L. Reinecke (Eds.), Privacy online (pp. 9-17). Berlin: Springer. https://doi.org/10.1007/978-3-64221521-6_2

Marin, M.-F., Morin-Major, J.-K., Schramek, T. E., Beaupré, A., Perna, A., Juster, R.-P., \& Lupien, S. J. (2012). There is no news like bad news: Women are more remembering and stress reactive after reading real negative news than men. PLoS ONE, 7(10), e47189.

https://doi.org/10.1371/journal.pone.004 7189

Mizuno, K., Tanaka, M., Yamaguti, K., Kajimoto, O., Kuratsune, H., \& Watanabe, Y. (2011). Mental fatigue caused by prolonged cognitive load associated with sympathetic hyperactivity. Behavioral and Brain Functions, $\quad$ 7(17), 1-7. https://doi.org/10.1186/1744-9081-7-17

Mohiyeddini, C., Bauer, S., \& Semple, S. (2015). Neuroticism and stress: The role of displacement behavior. Anxiety, Stress, \& 
Coping, 28(4), 391-407.

https://doi.org/10.1080/

10615806.2014 .1000878

Mukaromah, V. F. (2020). WHO gunakan istilah physical distancing, ini bedanya dengan social distancing. Diambil dari https://www.kompas.com/tren/read/202 0/ 04/01/061500965/who-gunakanistilah-physical-distancing-ini-bedanyadengan-social pada tanggal 15 April 2020.

Munzel, A., Galan, J. P., \& Meyer-Waarden, L. (2018). Getting by or getting ahead on social networking sites? The role of social capital in happiness and well-being. International Journal of Electronic Commerce, 22(2), 232-257. https://doi.org/10.1080/10864415.2018. 1441723

Pawar, S., Jacques, T., Deshpande, K., Pusapati, R., \& Meguerdichian, M. J. (2018). Evaluation of cognitive load and emotional states during multidisciplinary critical care simulation sessions. BMJ Simulation and Technology Enhanced Learning, 4(2), 8791. https://doi.org/10.1136/bmjstel2017-000225

Ramdhani, N. (2012). Adaptasi bahasa dan budaya Inventori Big Five. Jurnal Psikologi, 39(2), 189-207. https://doi.org/10.22146/jpsi.6986

Rapp, D. N., \& Salovich, N. A. (2018). Can't we just disregard fake news? The consequences of exposure to inaccurate information. Policy Insights from the Behavioral and Brain Sciences, 5(2), 232-239. https://doi.org/10.1177/2372732218785 193

Ravindran, T., Kuan, A. C. Y., \& Lian, D. G. H. (2014). Antecedents and effects of social network fatigue. Journal of the Associations for Information Science and Technology, 65(11), 2306-2320. https://doi.org/10.1002/asi.23122

Roos, J. M., \& Kazemi, A. (2018). Personality traits and Internet usage across generation cohorts: Insights from a nationally representative study. Current Psychology. https://doi.org/10.1007/s12144-0180033-2

Roosenbeek, J., \& van der Linden, S. (2019). Fake news game confers psychological resistance against online misinformation. Palgrave Communication, 5(65), 1-10. https://doi.org/10. 1057/s41599-0190279-9

Secon, H., Frias, L., \& McFall-Johnsen, M. (2020). A running list of countries that are on lockdown because the coronavirus pandemic. Diunduh dari https://www.business

insider.sg/countries-on-lockdown-

coronavirus-italy-2020-3?r=US\&IR=T

pada 31 Maret 2020.

Shokouhyar, S., Siadat, S. H., \& Razavi, M. K. (2018). How social influence and personality affect users'social network fatigue and discontinuance behavior. Aslib Journal of Information Management, 70(4), 344-366. https://doi.org/10.1108/AJIM-11-20170263

Sonowska, J., de Fruyt, F., \& Hofmans, J. (2019). Relating neuroticism to emotional exhaustion: A dynamic approach to personality. Frontiers in Psychology, 10, 2264.

https://doi.org/10.3389/fpsyg.2019.0226 4

Spitzer, R. L., Kroenke, K., Williams, J. B. W., \& Löwe, B. (2006). A brief measure for assessing generalized anxiety disorder. Archives of Internal Medicine, 166(10), 1092.

https://doi.org/10.1001/archinte.166.10. 1092

Srivastava, S. C., Chandra, S., \& Shirish, A. (2015). Technostress creators and job outcomes: theorising the moderating influence of personality traits. Information Systems Journal, 25(4), 355-401. https://doi.org/10.1111/isj.12067

Stein, M. B., \& Sareen, J. (2015). Generalized anxiety disorder. New England Journal of Medicine, 373(21), 2059-2068. https://doi.org/10.1056/nejmcp1502514

Strombach, T., Margittai, Z., Gorczyca, B., \& Kalenscher, T. (2016). Gender-specific effects of cognitive load on social discounting. PLoS ONE, 11(10), e0165289. https://doi.org/10.1371/ journal.pone.0165289

Tarafdar, M., Cooper, C. L., \& Stich, J.-F. (2019). The technostress trifecta - techno eustress, techno distress and design: Theoretical directions and an agenda for research. Information Systems Journal, 29, 6-42. https://doi.org/10.1111/isj.12169

Tarafdar, M., Tu, Q., Ragu-Nathan, B. S., \& RaguNathan, T. S. (2007). The impact of technostress on role stress and productivity. Journal of Management Information Systems, 24(1), 301-328. doi: 10.2753/mis0742-1222240109

Vannucci, A., Flannery, K. M., \& Ohannessian, C. M. (2017). Social media use and anxiety in emerging adults. Journal of Affective Disorders, 207, 163-166. 
https://doi.org/10.

1016/j.jad.2016.08.040

Wang, J., Korczykowski, M., Rao, H., Fan, Y., Pluta, J., Gur, R. C., McEwen, B. S., \& Detre, J. A. (2007). Gender difference in neural response to psychological distress. SCAN, 2 , 227-239. https://doi.org/10.1093/scan/nsm018

World Health Organization. (2020). Situation report-1. https://www.who.int/ emergencies/diseases/novel-coronavirus2019/situation-reports/

Widiger, T. A., \& Oltmanns, J. R. (2017). Neuroticism is a fundamental domain of personality with enormous public health implications. World Psychiatry, 16(2), 144-145. https://doi.org/10.1002/wps.20411

Xiao, L., \& Mou, J. (2019). Social media fatigue Technological antecedents and the moderating roles of the personality traits: The case of WeChat. Computers in Human Behavior, 101, 297-310. https://doi.org/10.1016/j.chb.2019.08.00 1

Xiao, L., Mou, J., \& Huang, L. (2019). Exploring the antecedents of social network service fatigue: A socio-technical perspective. Industrial Management \& Data Systems, 119(9), 2006-2032 https://doi.org/10.1108/IMDS-04-20190231
Yao, J., \& Cao, X. (2017). The balancing mechanism of social networking overuse and rational usage. Computers in Human Behavior, 75, 415-422. https://doi.org/10.1016/j.chb.2017. 04.055

Yu, L., Cao, X., Liu, Z., \& Wang, J. (2018). Excessive social media use at work: Exploring the effects of social media overload on job performance. Information Technology \& People, 31(6), 1091-1112. https://doi.org/10.1108/ITP-10-20160237

Zhang, S., Zhao, L., Lu, Y., \& Yang, J. (2016). Do you get tired socializing? An empirical explanation of discontinuous usage behavior in social network service. Information \& Management, 53, 904-914. https://doi.org/10.1016/j.im.2016. 03.006

Zhou, T., \& Li, H. (2014). Understanding mobile SNS continuance usage in China from the perspectives of social influence and privacy concern. Computers in Human Behavior, 37, 283-289. https://doi.org/10.1016/j.chb.2014.05.00 8

Zhou, M., \& Zhang, X. (2019). Online social networking and subjective well-being: Mediating effects of envy and fatigue. Computers \& Education, 140, 103598. https://doi.org/10.1016/j.compedu.2019. 103598 